\title{
Pengelolaan Sampah Dari Lingkup Terkecil dan Pemberdayaan Masyarakat sebagai Bentuk Tindakan Peduli Lingkungan
}

\author{
Ni Luh Putu Juniartini \\ Tim Fasilitator Lapangan (TFL) SNVT PUPR \\ email: juniraditya@gmail.com
}

\begin{abstract}
ABSTRAK
Indonesia sebagai penyumbang sampah plastik terbesar kedua di dunia setelah Cina memunculkan ungkapan darurat sampah plastik di Indonesia. Masalah global ini harus segera dilakukan tindakan nyata dari lingkup terkecil yaitu rumah tangga sebagai salah satu yang memproduksi sampah. Pemahaman tentang sampah dari jenis, sumber, dan bentuknya sangat perlu untuk disosialisasikan. Langkah sederhananya yakni membudayakan 5R (reuse, reduce, recycle, replace, repair) dalam membangkitkan kembali semangat peduli lingkungan dan pengelolaan sampah secara sederhana pada tingkat rumah tangga. Sebagai perantara awal adalah pada lingkup terkecil yaitu keluarga dalam wilayah desa. Salah satu yang perlu ditingkatkan kualitasnya adalah organisasi yang menaungi ibu-ibu yakni PKK tingkat desa karena perannya pada dua area penting, keluarga dan lingkungan desa. Pada sisi kualitas PKK desa, perlu mendapatkan edukasi terkait tentang pengolahan sampah secara sederhana, agar edukasi tersebut kemudian dapat secara berkelanjutan menuju ruang lingkup yang dinaungi. Selain pemberdayaan, pengetahuan tentang sampah akan memunculkan kreativitas pada pengelolaannya agar sampah yang dimaksud menjadi sesuatu yang dapat berdaya guna dan memberikan keuntungan. Hal ini akan berdampak pula pada proses lanjutan pengolahan daur ulang sampah pada fase berikutnya dan pada akhinya akan berdampak pula pada penekanan atau pengendalian sampah secara lebih luas dalam berbagai lapisan kehidupan masyarakat.
\end{abstract}

Kata Kunci: kelola, sampah, lingkungan, 5R, PKK.

\section{ABSTRACT}

Indonesia as the second-largest contributor to plastic waste in the world after China, gave rise to the expression of emergency plastic waste in Indonesia. This global problem must be immediately taken real action from the smallest scope, namely the household as one that produces waste. An understanding of waste from its type, source, and shape is essential to be socialized. The simple step is to cultivate $5 R$ (reuse, reduce, recycle, replace, repair) in reviving the spirit of environmental care and simple waste management at the household level. The initial intermediary is the smallest scope, namely families in the village area. One of the things that need to be improved is the organization that houses mothers, namely the PKK at the village level, because of its role in two critical areas, the family and the village environment. In terms of the quality of village PKK, it is necessary to get education related to simple waste management, so that education can then be continued towards the scope of which is sheltered. In addition to empowerment, knowledge about waste will bring creativity to its management so that the waste in question becomes something that can be effective and provide benefits. This will also have an impact on the continued process of 
processing waste recycling in the next phase and in the end, will also have an effect on suppressing or controlling waste more broadly from various walks of life.

Keywords: Management, waste, environment, 5R, PKK.

\section{PENDAHULUAN}

Sebelum membahas lebih jauh perihal sampah, ada baiknya kita mengetahui terlebih dahulu dari dampak global yang terjadi saat ini terkait sampah. Kalau kita cermati bersama, sampah selalu membawa polemik tak berujung, tidak hanya di Indonesia saja tetapi bahkan di seluruh dunia menghadapi poblematika yang sama yaitu tentang sampah. Masalah sampah memang tidak akan pernah ada habisnya semasih manusia mendiami planet bumi ini dan sepanjang itu pula permasalahan sampah akan terus dibahas dalam berbagai sudut pandang. Sampah selalu timbul menjadi persoalan rumit dalam masyarakat yang kurang memiliki kepekaan terhadap lingkungan. Ketidakdisiplinan mengenai kebersihan dapat menciptakan suasana semrawut akibat timbunan sampah. Begitu banyak kondisi tidak menyenangkan akan muncul, seperti bau tidak sedap, lalat berterbangan, dan gangguan berbagai penyakit siap menghadang di depan mata. Tidak cuma itu, peluang pencemaran lingkungan disertai penurunaan kualitas kesehatan dan keindahan pun akan menjadi santapan sehari-hari bagi masyarakat.

Merujuk pada Indonesia secara umum, kita tahu bersama bahwa negara kita dikatakan sebagai negara berkembang dan taukah kita bahwa Indonesia merupakan salah satu negara penyumbang sampah terbesar di dunia. Berdasarkan sumber publikasi dari salah satu televisi nasional, menurut Jambeck tahun 2015 dari University of Georgia dikatakan, Indonesia adalah penyumbang sampah terbesar kedua terutama sampah plastik dengan volume 187,2 juta ton/tahun, dengan China pada posisi pertama dengan 262,9 juta ton/tahun dan berikutnya setelah negara kita diikuti oleh Filipina, Vietnam, dan Sri Lanka. Adanya jumlah tersebut dapat diasumsikan bahwa Indonesia memproduksi sekitar 175 ribu ton/hari atau $0,7 \mathrm{~kg} /$ orang setiap harinya (News n.d.).

Berdasarkan kenyataan yang memprihatinkan ini, dapat dikatakan bahwa Indonesia saat ini dalam keadaan darurat sampah terutama sampah plastik. Inilah yang menjadi isu besar dan tugas kita bersama dalam menyikapi prihal sampah. Sampah merupakan objek yang kita tidak pedulikan, kemudian memunculkan masalah yang sangat pelik bagi kita dan lingkungan di masa depan. Berikutnya adalah muncul suatu pertanyaan, bagaimanakah kita memahami tentang sampah dan apa saja jenis 
dari sampah-sampah tersebut, maka dangan demikian kita dapat melakukan tindakan atas dasar pemahaman ini.

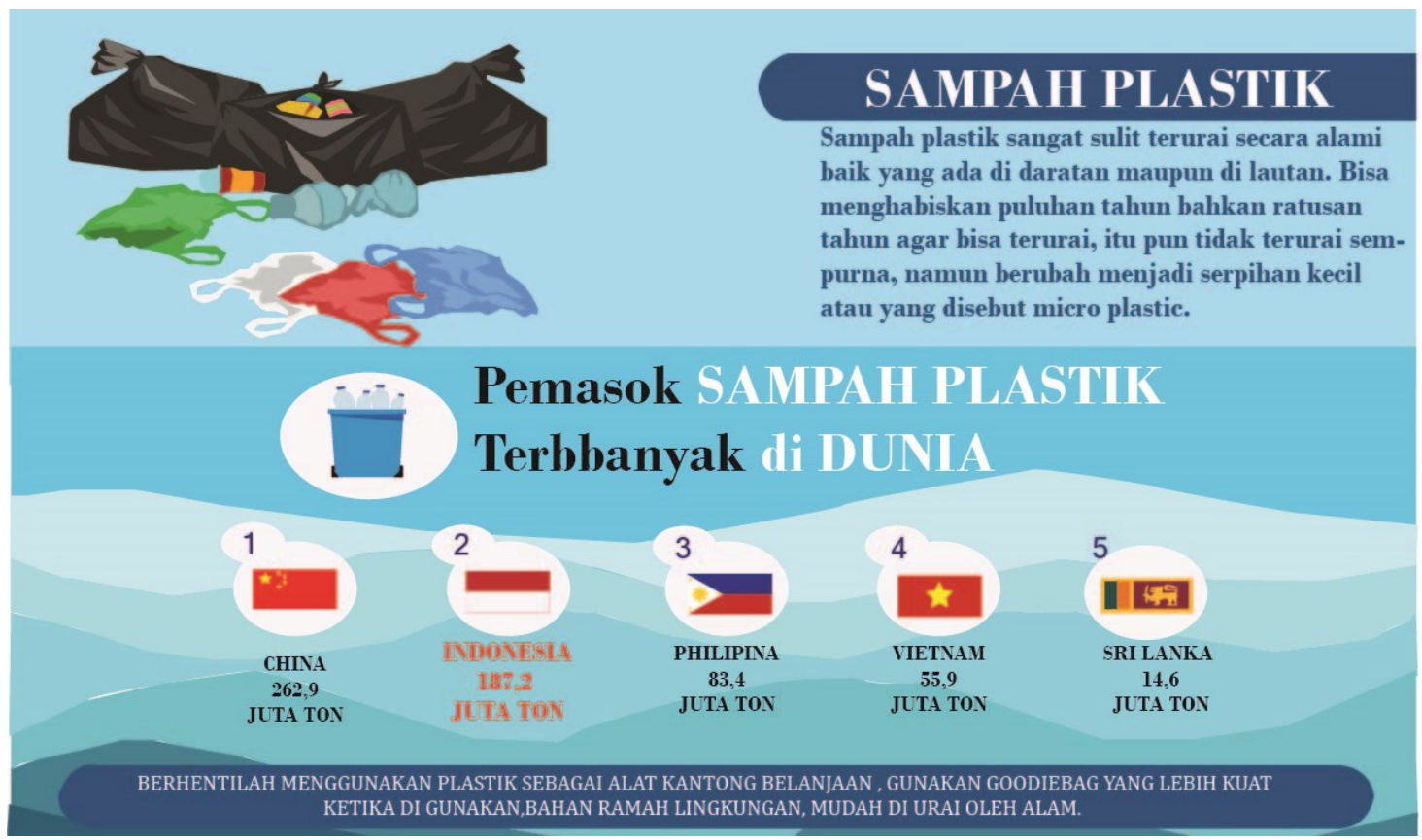

Gambar 1. Infografis pemasok sampah plastik terbanyak di dunia.

[Sumber: sablongoodiebag.com]

KAJIAN SUMBER
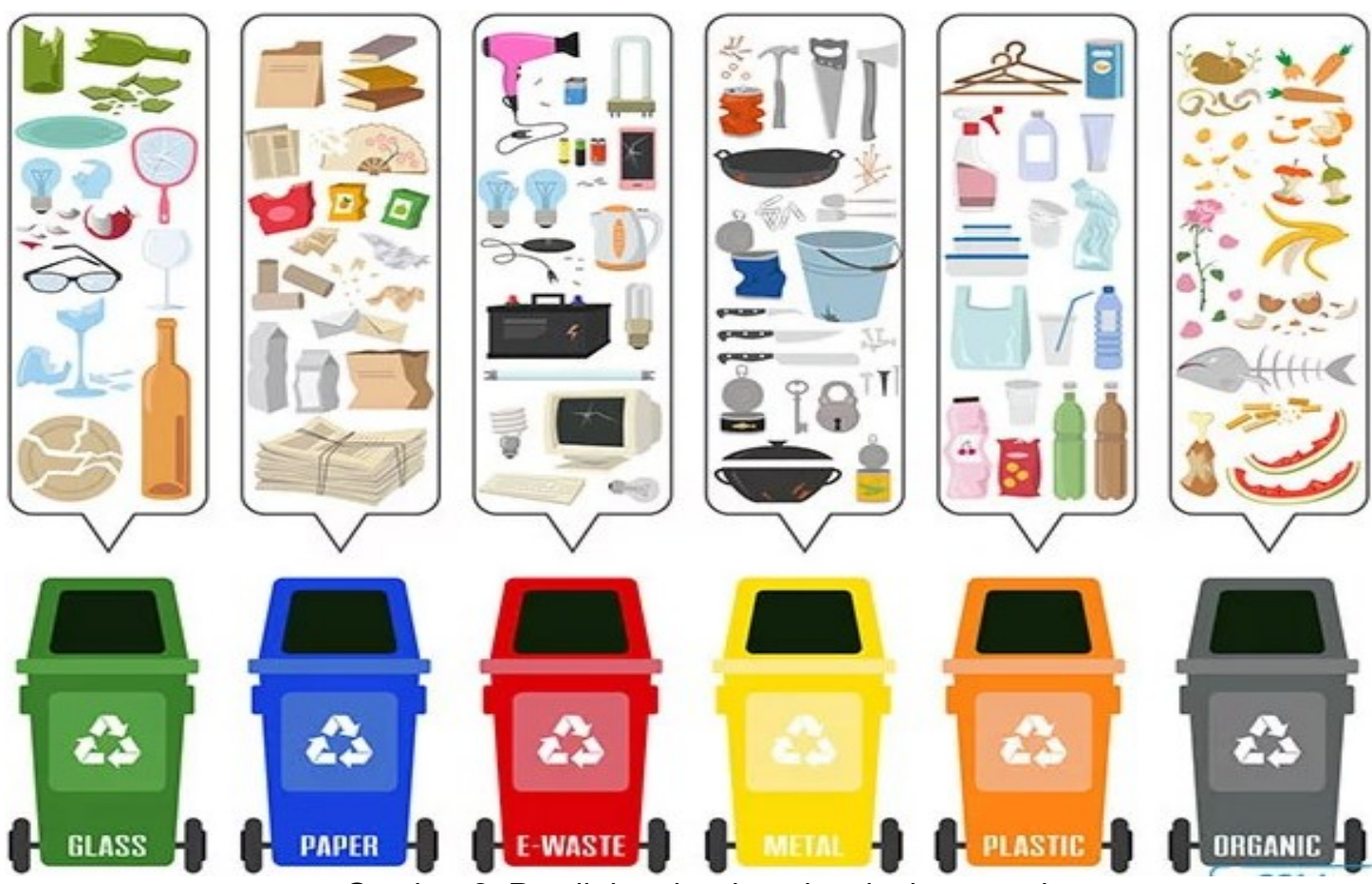

Gambar 2. Pemilahan berdasarkan jenis sampah.

[Sumber: 99.co] 
Berdasarkan jenis, terdapat tiga jenis sampah yang meliputi (Daniel 2009):

1. Sampah organik: sampah yang terdiri dari bahan-bahan yang bisa terurai secara alamiah/biologis, seperti sisa makanan dan guguran daun. Sampah jenis ini juga biasa disebut sampah basah.

2. Sampah anorganik: sampah yang terdiri dari bahan-bahan yang sulit terurai secara biologis. Proses penghancurannya membutuhkan penanganan lebih lanjut di tempat khusus, misalnya plastik, kaleng dan styrofoam. Sampah jenis ini juga biasa disebut sampah kering.

3. Sampah bahan berbahaya dan beracun atau disebut juga sampah B3: limbah dari bahan-bahan berbahaya dan beracun seperti limbah rumah sakit, limbah pabrik dan lain-lain.

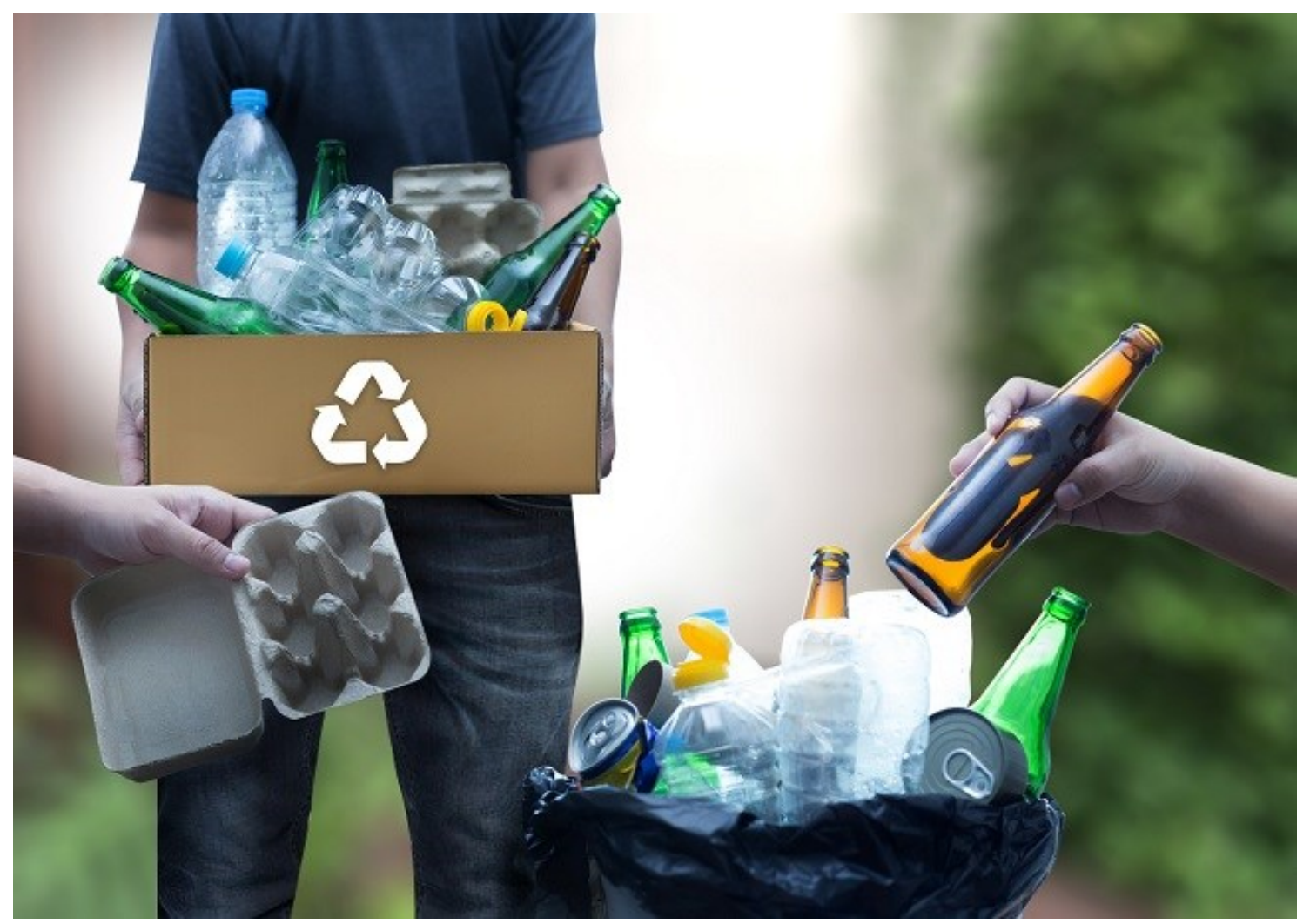

Gambar 3. Edukasi pemilahan sampah menurut jenisnya.

[Sumber: https://aetra.co.id/]

Secara prinsip, segala bentuk tindakan sederhana dalam menyikapi permasalahan sampah berujung pada 5 langkah besar yang disebut dengan $5 R$ (sebelumnya biasa disebut 3R) yaitu (Kusminah n.d.) (Sugiarti and Aliyah 2015):

1) Reduce (mengurangi): mulai untuk mengurangi produksi sampah yang dihasilkan oleh diri sendiri, dalam prakteknya seperti membawa tas belanja sendiri untuk 
mengurangi sampah kantong plastik atau membawa botol minuman daripada membeli minuman dalam kemasan.

2) Reuse (memakai): menggunakan kembali barang yang sudah tidak terpakai, contohnya seperti menggunakan plastik bekas belanja untuk pembungkus di kemudian hari, memakai kaleng bekas sebagai pot tanaman, atau memakai pakaian bekas sebagai lap, kerajinan tangan, dan lainnya.

3) Recycle (daur ulang): penanganan khusus dalam memanfaatkan inovasi teknologi dalam mengolah atau mendaur ulang sampah tertentu menjadi benda yang dapat digunakan kembali, contohnya kertas dari majalah dan surat kabar bekas, logam dari kaleng dan sendok bekas, kaca dari botol dan gelas bekas, serta lainnya.

4) Replace (mengganti): yaitu mengusahakan untuk menggunakan barang ramah lingkungan yang bisa digunakan lebih dari sekali pemakaian, misalnya mengganti kantong plastik kresek dengan tas belanja lainnya sehingga dapat digunakan berulang kali, menghindari kemasan styrofoam dengan alternatif lain.

5) Repair (memperbaiki): memperbaiki barang yang rusak, dengan demikian barang tersebut dapat digunakan kembali. Misalnya barang elektronik yang rusak diperbaiki dengan komponen yang sesuai untuk permabaikannya, namun ini memerlukan keahlian khusus.

Berdasarkan prinsip dasar tersebutlah, implementasi pengelolaan sampah secara sederhana dapat dilakukan. Misalnya hal yang paling lumrah kita lihat seharihari untuk mengelola sampah rumah tangga, pada kenyataannya merupakan hal yang sudah biasa terjadi apabila rumah tangga memproduksi sampah setiap harinya. Sampah pada rumah tangga yang kian menumpuk dan bila tidak segera dibuang tentunya memiliki dampak yang tak baik untuk penghuni. Disinilah peran antar anggota keluarga, diperlukan kesadaran akan pentingnya mengelola sampah menjadi tonggak utama dalam menjaga rumah tinggal agar jauh dari kata kotor. Lantas, bagaimana cara mengelola sampah rumah tangga? Disini terdapat beberapa tindakan sederhana dan penting pula dalam mendukung proses lanjutan dari pengelolaan sampah dari rumah tangga yaitu (Faiga n.d.):

1) Memilah sampah menjadi 4 bagian: dengan menyediakan tempat berukuran besar untuk 4 kategori sampah yakni untuk sisa makanan, sampah plastik atau sejenisnya, sampah kertas, dan sampah kaca.

2) Mengganti tempat sampah rumah tangga: hal ini maksudnya mengurangi tempat penampungan sampah kecil di dalam rumah dan menggantinya dengan penampungan yang lebih besar di luar rumah sehingga dapat menampung sampah lebih banyak. Dengan demikian, sampah yang ada di rumah dapat langsung 
diangkut masuk ke Bank sampah yang ada. Selain itu, juga dapat memanfaatkan penggunaan ember bekas untuk menampung sampah organik.

3) Mengelola sampah dengan bank sampah: setorlah karung dengan sampah yang masih dapat dimanfaatkan secara periodik. Selanjutnya, jika terdapat bank sampah, akan meneruskan sampah tersebut ke petugas sampah untuk diolah kembali.

4) Pastikan botol yang dibuang dalam keadaan kering: air di dalam botol apabila masih tersisa harus dibuang. Botol yang basah akan menimbulkan efek becek dan kotor serta hal ini dapat menyebabkan bau busuk disekitar lingkungan rumah.

5) Buang sampah pada waktu yang tepat: sampah organik lebih cepat membusuk dan berbau merupakan sampah yang biasa ada di dapur. Bila sampah bertahan sampai malam hari maka akan mengundang kecoa dan hewan lainnya. Untuk itu, pastikan waktu yang tepat membersihkan dapur dan tempat lainnya secara benar.

6) Tempat sampah di rumah sebaiknya dalam keadaan tertutup: tempat sampah dalam keadaan tertutup akan menyebabkan bau tidak sedap yang dihasilkan oleh sampah tidak akan menyebar keluar ruangan dan mencemari udara sekitar.

7) Lakukan pengolahan sampah dan manfaatkan kembali: meskipun terkesan tak berguna, nyatanya sampah rumah tangga yang dibuang masih bisa dimanfaatkan kembali. Dari sampah rumah tangga tersebut, yang harus segera dilakukan pengolahan adalah sampah sisa makanan. Bila tidak segera diolah selama 3 hari atau lebih, sampah sisa makanan ini akan menimbulkan bau menyengat karena termasuk jenis sampah yang cepat membusuk. Sampah sisa makanan ini dapat diolah menjadi pupuk tanaman atau kompos. Setiap penghuni rumah membuat komposter sendiri untuk menghadapi masalah sampah rumah tangga. Sedangkan sampah berbahan kertas dan sampah berbahan plastik, dapat dijual ke pengepul sampah dan menjadi penghasilan tambahan.

Pengelolaan secara sederhana prihal sampah yang telah disebutkan, adalah turunan dari $5 R$ yang telah dijelaskan sebelumnya. Sebenarnya jika dekembangkan lebih lanjut, turunan-turunan yang ada, akan menjadi semakin kompleks dan memiliki sinergi dengan turunan aksi yang lainnya. Pada intinya adalah inovasi gagasan dengan aksi, pada ungkapan lain dari kegiatan prihal pengelolaan secara sederhana. Proses kegiatan tersebut diekstraksi kembali melalui inovasi ide atau kreativitas menjadi aksiaksi baru yang lebih bermanfaat dan menguntungkan serta memiliki kolaborasi lingkup kerja yang lebih luas sebagai tindakan peduli lingkungan. 
Berikutnya, pemberdayaan berbagai lapisan dalam mengelola sampah tentunya harus digiatkan, mengingat kembali hal ini harus mendapat dukungan banyak pihak. Sebagai suatu tindakan yang kreatif dan inovatif dengan aksi sederhana serta dapat merubah sampah menjadi objek yang berdaya guna memberikan keuntungan, contoh sederhananya seperti berikut:

Mengolah sampah organik:

1) Metode kascing: Kascing adalah kependekan dari bekas cacing, yaitu metode kompos yang dihasilkan melalui produk yang dikeluarkan oleh cacing atau dengan kata lain menggunakan cacing sebagai agen pengubah sampah menjadi kompos. Tata cara: media yang digunakan dalam metode kascing menggunakan tanah, kompos, dan kotoran hewan (misal kotoran sapi) dengan perbandingan $1: 1: 3$. Setelah semua diaduk, media tersebut dimasukkan ke dalam wadah dengan ditambahkan air, sehingga kadar air media menjadi 55\%. Lalu cacing tanah (cacing kalung) ditambahkan ke dalam media dengan jarak $5 \mathrm{~cm}$. Tinggi media tidak boleh lebih dari $60 \mathrm{~cm}$ sebab perlu diingat bahwa cacing sifatnya sering masuk dan ke luar dari tanah untuk bernapas. Kisaran saat cacing masuk ke dalam tanah sekitar $60 \mathrm{~cm}$ dan jika lebih dari itu, cacing tidak mau. Jadi kemungkinan besar, media yang berada di bawah $60 \mathrm{~cm}$ dari permukaan, tidak akan 'diolah' cacing. Sekitar 2 hari dari penambahan cacing sudah bisa dipanen dan jumlah kascing biasanya setengah dari jumlah cacing yang ditambahkan. Misalnya ditambah cacing $1 \mathrm{~kg}$, maka kascing yang dipanen sekitar $0,5 \mathrm{~kg}$ dan dapat dilakukan setiap hari.

2) Metode komposter pot: metode komposter pot ini menggunakan pot sesuai namanya. Jadi, sampah yang diolah menjadi kompos tidak perlu dikeluarkan dari pot tetapi sudah langsung menjadi media tanam. Jika sudah siap dimanfaatkan tinggal memasukkan bibit tersebut ke dalam komposter pot tersebut tanpa perlu penambahan apapun.

Tata cara: komposter pot terdiri atas kerikil atau ranting-ranting kecil di bagian terbawah (sebagai area untuk pengaliran air), kompos sedikit, sampah dapur yang sudah dicacah dengan ukuran maksimal $5 \mathrm{~cm}$, dan lalu ditutup dengan tanah. Jika masih tersisa ruang, tambahkan sampah, ditutup dengan tanah, dan begitu seterusnya sampai penuh. Lalu diamkan selama 1 bulan sampai teksturnya menyerupai kompos dan dapat langsung ditanami bibit tumbuhan.

3) Komposter rumah tangga: tempat membuat kompos yang ukurannya besar dan ditanam di dalam tanah di sekitar rumah. Untuk 1 rumah tangga, komposter ini bisa penuh dalam waktu 7 bulan dan didiamkan selama 3 bulan untuk dipanen. 
Tata cara: komposter seperti ini perlu disediakan 2 tempat, sehingga pada durasi tunggu tersebut kita dapat memasukkan sampah ke komposter tanam yang lain. Kompos yang dihasilkan, sebelum dipakai sebagai media tanam harus dicampur tanah dengan perbandingan kompos : tanah $1: 3$, dan perlu diingat kompos bersifat panas sehingga tidak disarankan dijadikan media tanam sesaat setelah dibuat. Metode ini dapat pula dilakukan dengan membuat dan memanfaatkan lubang-lubang biopori pada pekarangan selain fungsinya untuk lubang resapan.

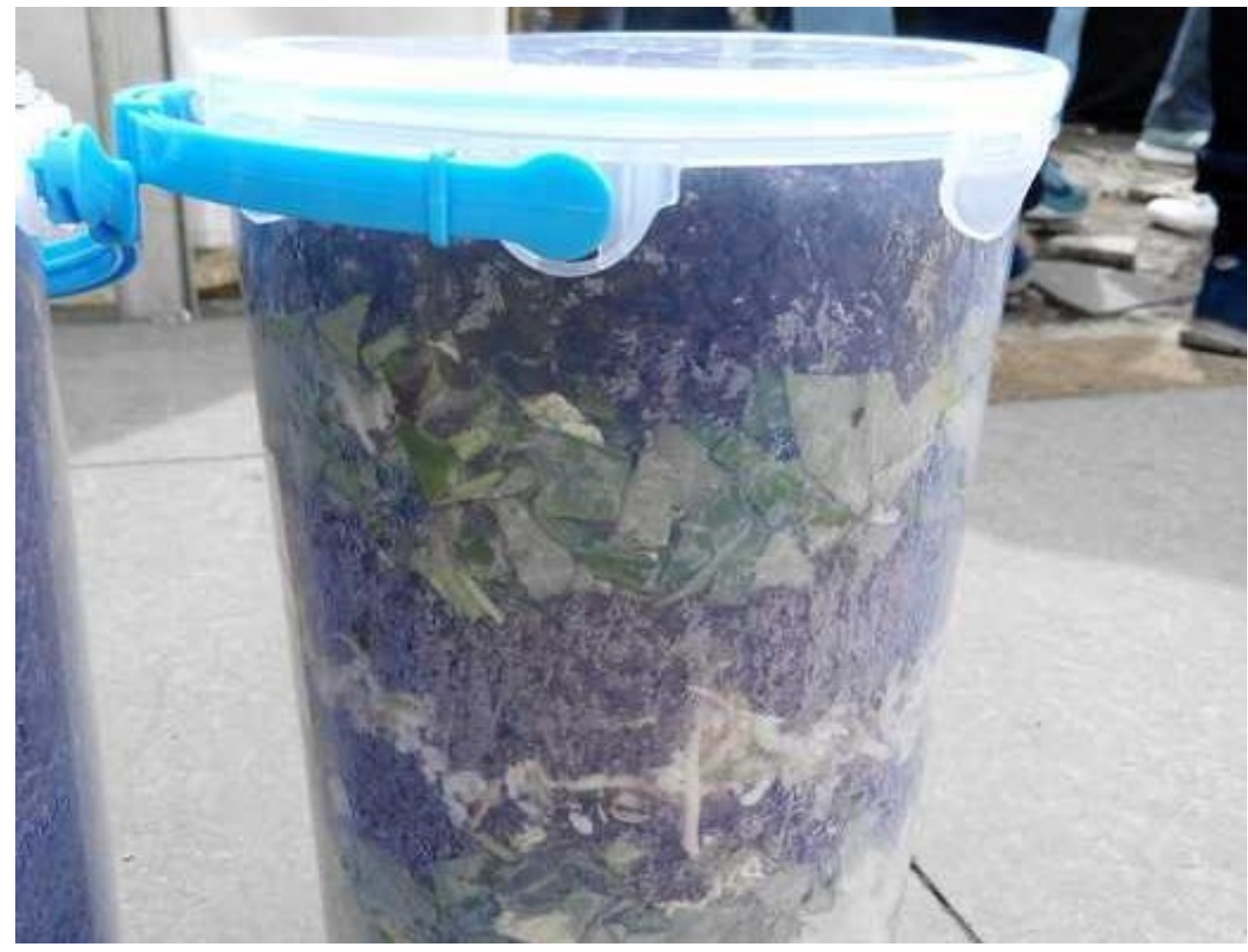

Gambar 4. Metode komposter pot [Sumber: kompasiana.com]

Mengolah sampah anorganik dikelola secara sederhana dengan melakukan prinsip reuse, misal memilih, memilah, dan menggunakan kembali barang yang dapat dipakai berulang kali. Contoh tindakan ini seperti memanfaatkan botol atau ember plastik bekas sebagai wadah untuk metode komposter ataupun kascing. Sedangkan yang berbahan kertas atau kemasan dapat dimanfaatkan untuk kreatifitas lain yaitu membuat kerajinan rumah tangga misalnya untuk kertas dapat dikelola menjadi tempat buah, tempat tissu, dan sebagainya. Untuk kemasan plastik atau sejenisnya dapat dijadikan kerajinan tas belanja, wadah media tanam, dan sebagainya. Selebih dari itu, 
pengolahan sampah anorganik dipilah lalu disalurkan ke pengepul sampah untuk menjalani proses lanjutan atau daur ulang. Mengapa hal ini dilakukan? Karena proses daur ulang pada sampah anorganik yang tidak bisa dikelola pada rumah tangga, memerlukan dukungan teknologi untuk pengelolaannya serta membutuhkan infrastruktur serta kompetensi sumber daya yang tepat, seperti mesin khusus untuk pengolahan lanjutan agar dapat menjadi barang yang lebih bermanfaat.

\section{Solusi Sederhana}

Seperti yang telah disebutkan sebelumnya, pengelolaan harus didukung dari aksi nyata semua pihak, sebagai contohnya didirikannya bank sampah pada tingkat desa yang dikelola secara mandiri oleh desa setempat dengan memberdayakan kreatifitas ibu-ibu PKK. Contoh pada kegiatan ini misal dalam pemilahan sampah dari rumah dan pada tempat pengelolaan lanjutan untuk didaur ulang pada bank sampah. Proses ini selain dapat membuat lingkungan bersih, dapat pula memberikan penghasilan tambahan pada ibu-ibu PKK. Selain itu, PKK desa sebagai ujung tombak rumah tangga agar ditingkatkan produtifitasnya, misalnya dalam pengkaderan yang baik, memberikan pembekalan, atau pelatihan tentang sampah dan pengolahannya, serta membangun kreativitas dalam mengelolaan sampah untuk nilai ekonomi. Adanya peningkatan produktivitas dan kualitas dari organisasi PKK desa, selanjutnya dapat diberdayakan kembali sebagai tim penyuluh lapangan tentang sampah. Penugasan ini dapat dipilih berdasarkan yang berprestasi dalam organisasi dan diperlukan pula apresiasi dari pemerintah atas hal ini. Sasaran dari penyuluhan tersebut diantaranya meng-edukasi anak-anak, kepemudaan, lansia dan komponen lainnya agar ikut bersama, bersinergi, dan berkolaborasi dalam pemanfaatan serta pengelolaan sampah disamping untuk kesehatan dan kebersihan lingkungan. Selain itu, tindakan edukasi ini juga perlu ada aksi nyata yaitu melakukan tindakan-tindakan dalam mengkondisikan situasi dengan ikut andil bersama pada pengelolaan sampah dari berbagai lapisan masyarakat dari lingkup terkecil sampai pada wilayah secara berkelanjutan.

\section{Solusi Lanjut}

Pada solusi lanjut diperlukan adanya kerjasama atau kemitraan yang bersifat saling menguntungkan, baik pemerintah, akademisi, praktisi, dan swasta. Kerjasama ini terkait dengan bantuan pengalaman, pengetahuan, dan pendanaan untuk meningkatkan ketersediaan sumber daya dan infrastruktur terkait. Contohnya, pengolahan sampah pada sampah anorganik yang membutuhkan proses lanjutan yaitu kebutuhan alat olah sampah menuju hasil jadi produk-produk daur ulang. Pada misi ini 
tentunya pula, solusi sederhana yang telah dilakukan akan menjadi penting untuk mempercepat linkaran proses pengelolaan sampah, misalnya pemilahan sampah kering anorganik seperti kertas, kaca, metal tidak lagi membutuhkan waktu lebih banyak di pengepul sampah untuk dipilah ulang.

Pada tahap yang lebih tinggi, pengolahan sampah mulai lebih kompleks dan tidak dalam kategori sederhana lagi, karena membutuhkan infrastruktur teknologi terkini seperti mesin-mesin pemilah partikel material yang dapat dimanfaatkan pada berbagai jenis sampah. Sebagai informasi tambahan, banyak hal dapat ditambang dari sampah-sampah ini dengan bantuan olahan teknologi terkini diantaranya:

1) Sampah atau limbah elektronik jika diolah daur ulang secara benar dengan dukungan alat dan teknologi yang tepat guna dapat menghasilkan timbel, tembaga, perak, dan bahkan emas, karena bahan tersebut dimanfaatkan pada komponen elektronik (Wahyono n.d.).

2) Sampah dari limbah plastik selain di daur ulang menjadi bahan kerajinan, mainan, atau kembali menjadi bijih plastik, juga dapat di daur menjadi aspal jalan, bahkan dengan teknologi hydrothermal dapat menghasilkan BBM seperti minyak tanah dan solar, selain itu plastik dapat di daur berulang kali (Australia n.d.).

3) Sampah kaleng dan logam jika didaur ulang dapat menjadi bahan dasar besi, baja, atau alumunium (Awali et al. n.d.).

4) Sampah kertas dapat didaur ulang menjadi kerajinan rumah tangga, selain itu dapat pula dijadikan bubur kertas untuk diolah kembali menjadi kertas lembaran yang berbasis daur ulang (Arfah n.d.).

5) Limbah kaca selain dapat dijadikan kerajinan, jika di daur dengan proses pelelehan panas maka dapat dimanfaatkan lagi dari secara beragam menjadi perabotan rumah tangga, cermin, dekorasi, dan sebagainya (Sylvia and Mahmudah 2018).

6) Sampah untuk pembangkit tenaga listrik, hal ini dapat dilakukan dengan memanfaatkan energi panas dari pembakaran sampah dan fermentasi metana atau memanfaatkan gas metana yang dihasilkan dari tumpukan sampah. Prosesproses tersebut intinya memanfaatkan panas dari hasil pembakaran dan akumulasi gas untuk menggerakkan turbin guna menghasilkan listrik (Wikipedia n.d.). Selain itu, dipublikasikan pula bagaimana infrastruktur ini bekerja pada pameran teknologi terkini pada peringatan Hari Teknologi Nasional dengan inisiasi dari KEMENRISTEK DIKTI yang diadakan di lapangan puputan Renon di tahun 2019. 


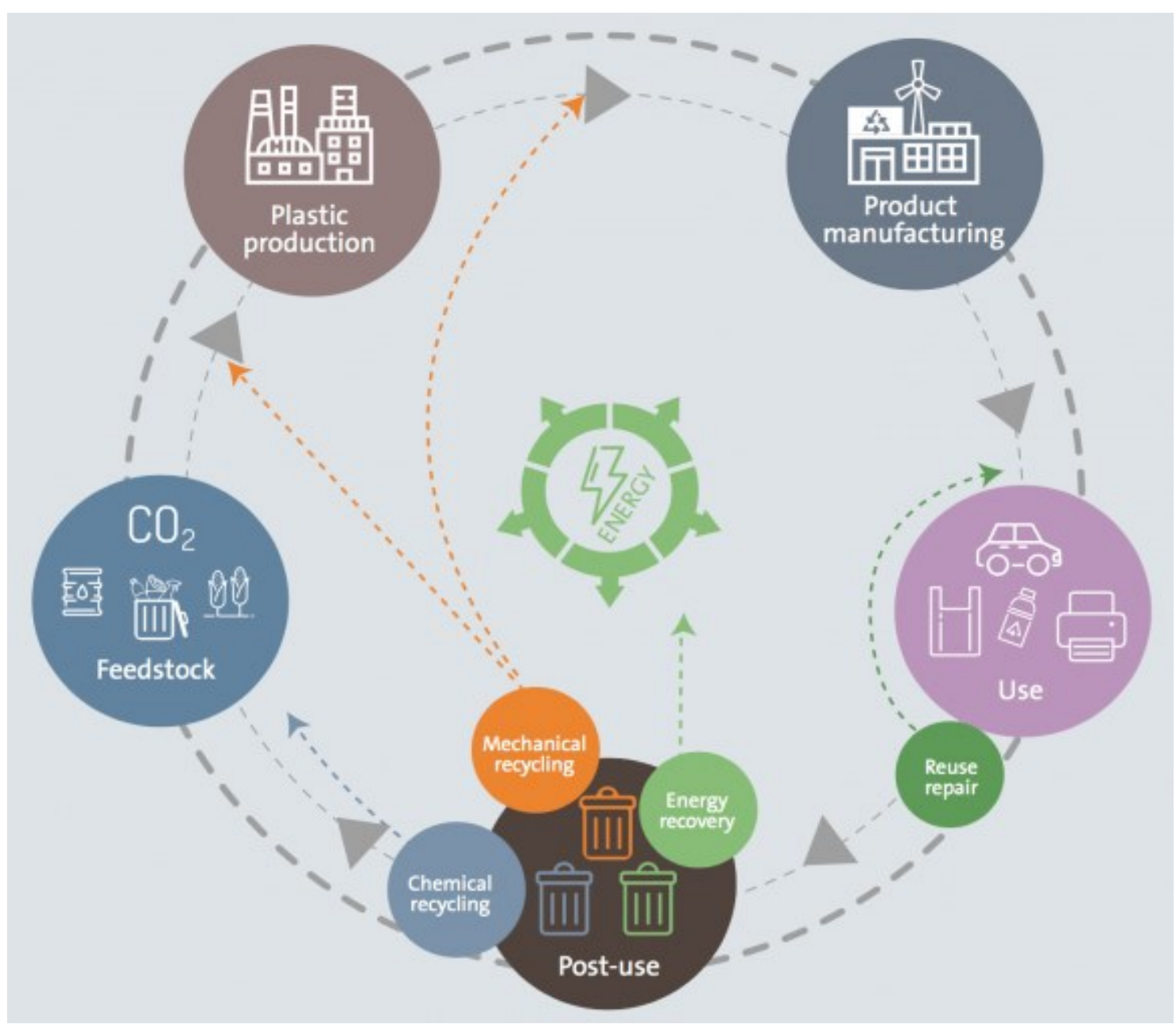

Gambar 5. Pengolahan sampah dengan dukungan teknologi terkini. [Sumber: https://journals.openedition.org/]

Kembali pada topik bahasan awal yaitu pengolahan sampah secara sederhanai, dapat kita tinjau kembali bahwa segala bentuk proses adalah memetakan jalur sampah mulai dari mana sampah-sampah ini diproduksi. Dengan melakukan tindakan nyata sedari awal proses, maka secara otomatis akan dapat mempercepat pula pada proses-proses berikutnya pada tindakan daur ulang. Lingkaran proses ini akan terus berotasi sehingga dapat menekan dan mengendalikan sampah menjadi objek yang berdaya guna dan memiliki nilai ekonomi. Oleh karena itu, kita bersama harus memperkuat komponen ujung tombak yang telah disebutkan diawal sebelumnya, dengan demikian meng-edukasi masyarakat akan kesadaran untuk mengelola sampah dari diri sendiri dan rumah tangga sangatlah penting. 


\section{SIMPULAN DAN SARAN}

Berdasarkan ulasan yang telah dilakukan, dapat disimpulkan beberapa hal yakni:

1) Masyarakat dapat menyadari pentingnya kepedulian akan lingkungan sekitar dengan cara memahami pentingnya pengolahan sampah secara tepat guna untuk menciptakan lingkungan yang bersih dan sehat.

2) Masyarakat dapat pula memahami prinsip $5 R$ dan peranan bank sampah, sehingga masyarakat mampu memanfaatkan sampah sebagai penghasilan tambahan.

3) Membentuk kelompok-kelompok kerja dengan memberdayakan masyarakat dan organisasi terkait sebagai langkah awal pengelolaan sampah sebagai tanggung jawawb bersama.

4) Sampah yang diproduksi oleh masing-masing rumah dikelola dengan cara dipilah dan ditempatkan terpisah sesuai dengan jenis sampah organik dan anorganik, hal tersebut dapat mempermudah tugas pengepul atau petugas sampah untuk diproses lebih lanjut.

Pada kegiatan ini, diperlukan kolaborasi atau sinergi semua pihak agar tindakan peduli lingkungan melalui pengelolaan sampah ini berjalan baik, maka diperlukan pula sebagai berikut:

1) Pengelolaan sampah memerlukan pengawasan dari semua pihak berdasarkan ruang lingkupnya, misal pada rumah tangga diawasi oleh ibu atau bapak, pada tingkat desa diawasi oleh perangkat atau organisasi di desa bersangkutan, dan pada akhirnya peranan pemerintah diperlukan dalam pengawasan lingkup yang lebih besar.

2) Peran aktif seluruh komponen masyarakat untuk memilah sampah untuk mempermudah proses selanjutnya dalam pengelolaan sampah dengan melaksanakan $5 \mathrm{R}$ dan terus memberikan pemahaman bahwa prihal sampah adalah tanggung jawab bersama.

\section{REFERENSI}

Arfah, Mahrani. Pemanfaatan Limbah Kertas Menjadi Kertas Daur Ulang Bernilai Tambah Oleh Mahasiswa. Buletin Utama Teknik 13(1).

Alex, S. 2012. Sukses Mengolah Sampah Organik Menjadi Pupuk Organik. Yogyakarta: Pustaka Baru Press.

Australia, ABC. IImuwan Australia Temukan Kemungkinan Solusi Daur Ulang Sampah Plastik. Tempo.co. https://www.tempo.co/abc/4990/ilmuwan-australia-temukankemungkinan-solusi-daur-ulang-sampah-plastik (January 15, 2020).

Awali, Jatmoko et al. Pelatihan Daur Ulang Logam (Aluminium) Bagi Masyarakat 
Karang Joang. Jurnal Pengabdian kepada Masyarakat - Indonesian Journal of Community Engagement 4(1): 1-10.

Bali, Gubernur. 2018. Peraturan Gubernur Bali Nomor 97 Tahun 2018, Tetang Pembatasan Timbulan Sampah Plastik Sekali Pakai.

Daniel, Valerina. 2009. Easy Green Living. Bandung: Hikmah.

Faiga, Gama. 7 Cara Mengelola Sampah Rumah Tangga. Kompasiana. https://www.kompasiana.com/gamafaiga/5d8141550d82305955411582/7-caramengelola-sampah-rumah-tangga?page=all (January 14, 2020).

Kusminah, Imah Luluk. Penyuluhan 4R (Reduce, Reuse, Recycle, Replace) Dan Kegunaan Bank Sampah Sebagai Langkah Menciptakan Lingkungan Yang Bersih Dan Ekonomis Di Desa Mojowuku Kabupaten Gresik. Jurnal Pengabdian Masyarakat LPPM Untag Surabaya 3(1): 22-28.

News, Metro TV. Indonesia Darurat Sampah Plastik. https://www.youtube.com/watch?v=ggAujyp4OYA.

Sugiarti, Rara, and Istijabatul Aliyah. 2015. Budaya Pengelolaan Sampah Berbasis Masyarakat Melalui Metode 5R Untuk Mewujudkan Lingkungan Bersih Dan Sehat Di Kabupaten Sukoharjo. Jurnal UNS Cakra Wisata 16(2): 9-22.

Sylvia, Nukke, and Nur Lailiyah Mahmudah. 2018. "Tinjauan Proses Dan Teknik Flameworking Pada Limbah Kaca." NARADA, Jurnal Desain \& Seni, FDSK $U M B 5(2)$.

Wahyono, Sri. Kebijakan Pengelolaan Limbah Elektronik Dalam Lingkup Global Dan Lokal. Jurnal Teknologi Lingkungan 14(1): 17-24.

Wikipedia, Contributor. Pembangkit Listrik Tenaga Sampah. Wikipedia Bebas. https://id.wikipedia.org/wiki/Pembangkit_listrik_tenaga_sampah (January 15, 2020). 
